\title{
Pathology of Edwardsiella tarda infection in African catfish, Clarias gariepinus (Burchell 1822), fingerlings
}

\author{
Thangapalam Jawahar Abraham, Prakash Kumar Mallick, Harresh Adikesavalu, \\ Sayani Banerjee
}

Received - 04 July 2015/Accepted - 28 August 2015. Published online: 31 October 2015; @Inland Fisheries Institute in Olsztyn, Poland Citation: Abraham T.J., Mallick P.K., Adikesavalu H., Banerjee S. 2015 - Pathology of Edwardsiella tarda infection in African catfish, Clarias gariepinus (Burchell 1822), fingerlings - Arch. Pol. Fish. 23: 141-148.

\begin{abstract}
Edwardsiella tarda is one of the serious fish pathogens infecting both cultured and wild fish species. This study aimed to assess the phenotypic characterization and pathogenicity of E. tarda isolated from Clarias gariepinus (Burchell) with dropsy and histopathological alterations. The causative agent was identified with Vitek 2, and its pathogenicity was determined by intramuscular injection. The challenged catfish exhibited vertical hanging, frothing, excess mucus production, listing, swollen abdomen, anorexia, fin and tail rot, and reddish operculum. The $\mathrm{LD}_{50}$ of E. tarda $\mathrm{PB}_{\mathrm{B}}$ and $\mathrm{PB}_{\mathrm{P}}$ strains was found to be $8.52 \times 10^{6}$ and $1.68 \times 10^{7}$ cells fish $^{-1}$, respectively. Histopathological observations on catfish infected naturally revealed lymphocyte infiltration in muscle and focal necrosis, hyperplasia, edema, and swelling of the gill lamellar epithelium. The kidney of diseased fish exhibited ischemic type tubulopathy, necrosis of nephritic tubules, hyperplastic hematopoietic tissue, rupture of the tubular basement membrane, hydropic dystrophy of nephritic cells, neutrophil infiltration, fibrinoid necrosis of nephretic tubules, hemosiderin deposition, and edema. The liver sections revealed lymphocyte infiltration, dilation of hepatic sinusoids, expansion of space between hepatic sinusoids, and focal necrosis. The inflammatory responses observed in kidney and liver in the present study were presumably suppuration and were attributed to the potential virulence factors of E. tarda.
\end{abstract}

T.J. Abraham ["”], P.K. Mallick, H. Adikesavalu, S. Banerjee Department of Aquatic Animal Health, Faculty of Fishery Sciences, West Bengal University of Animal and Fishery Sciences, Chakgaria, Kolkata - 700094, West Bengal, India

e-mail: abrahamtj1@gmail.com
Keywords: Edwardsiella tarda, Clarias gariepinus, pathogenicity, histopathology, necrosis, lymphocyte infiltration.

\section{Introduction}

The African catfish, Clarias gariepinus (Burchell), is considered widely to be one of the most important tropical catfish species for aquaculture. Not native to Indian waters, this species had a clandestine entry into India, first into West Bengal, and later it spread to other states (Thakur 1998). The introduction of this species has raised many concerns because of its negative impacts on native fish fauna through predation (Thakur 1998). The culture of C. gariepinus in rural ponds, tanks, cement cisterns, and even derelict waters using chicken and slaughter house wastes as feed is very common in India. This catfish has become an excellent aquaculture species, not only because of its tolerance of environmental extremes, but also for its high annual production, high growth rate, and high feed conversion rate (Singh and Lakra 2011). Fish are susceptible to a wide variety of bacterial pathogens especially when they are subjected to stressors, i.e., poor water quality and overstocking. Infectious diseases are the main cause of economic losses in the aquaculture industry, which is

(c) Copyright by Stanisław Sakowicz Inland Fisheries Institute in Olsztyn.

(c) 2015 Author(s). This is an open access article licensed under the Creative Commons Attribution-NonCommercial-NoDerivs License

(http://creativecommons.org/licenses/by-nc-nd/3.0/). 
negatively impacted by various bacterial pathogens. The most important bacterial diseases in tropical fish culture systems are hemorrhagic septicemia caused by Aeromonas spp. (Hidalgo and Figueras 2012), edwardsiellosis associated with E. tarda (Sahoo et al. 2000, Mohanty and Sahoo 2007, Park et al. 2012), and columnaris disease caused by Flavobacterium columnare (Declercq 2013). Edwardsiellosis is a septicemic disease characterized by extensive lesions in the skin, muscle, and internal organs that infects commercially important fish including eels, channel catfish, mullet, chinook salmon, flounder, carp, tilapia, and striped bass (Park et al. 2012).

In recent years, catfish farming has been growing in importance in West Bengal. Catfish production in India and West Bengal has been on the rise thanks to the high economic returns that can be made from modest investments. Following Andhra Pradesh, the state of West Bengal has held the second position in catfish production since 2008. The contribution of West Bengal's catfish production has been in the range of $16-20 \%$ of the total catfish production of India since 2007 (DAHDF 2012). Incidences of diseases in catfish aquaculture are increasing because of the intensification of culture practices. The present study recorded the phenotypic characteristics of $E$. tarda isolated from diseased C. gariepinus with dropsy, its pathogenicity, and the histopathological caused by natural infection.

\section{Materials and Methods}

\section{Bacteriology}

Morbid African catfish, Clarias gariepinus, fingerlings with dropsy $(\mathrm{n}=15)$ and healthy individuals $(n=15)$ from a disease-affected pond located in Naihati (2288’81”N; 8845’23”E), North 24 Parganas district, West Bengal were brought to the laboratory in oxygen-filled polythene bags. At the laboratory, the fish were first rinsed in sterile physiological saline, wiped with sterile paper towels, and dissected aseptically. Inocula from kidney and ascites, and also from the kidney of healthy fingerlings were streaked on to brain heart infusion agar (BHIA) and incubated at $30 \pm 2^{\circ} \mathrm{C}$ for $24 \mathrm{~h}$. Representative colonies based on dominance and distinct colony morphology were picked randomly from the BHIA plates, purified by repeated streaking on BHIA plates, and maintained on BHIA slants. A series of biochemical reactions were performed (Collins 2004, Austin and Austin 2012) to identify the bacterial strains isolated from kidney and ascites. Definite identification of two bacterial strains $\left(\mathrm{PB}_{\mathrm{B}}\right.$ and $\mathrm{PB}_{\mathrm{P}}$ ) was done with an automated bacterial identification system (Vitek 2 - Compact, BioMerieux, France).

\section{Determination of $\mathrm{LD}_{50}$ of Edwardsiella tarda strains}

Twenty 5001 capacity fiberglass reinforced plastic (FRP) tanks were selected, cleaned, disinfected, and dried. All the tanks were filled with clean bore-well water and were labeled as T1, T2, T3, and T4 for $E$. tarda $\mathrm{PB}_{\mathrm{P}}$ strain and T5, T6, T7, and T8 for E. tarda $\mathrm{PB}_{\mathrm{B}}$ strain. Positive (injected with sterile saline, $\mathrm{C}^{+}$) and negative (no injection, $\mathrm{C}^{-}$) controls for each strain were also maintained. All the tanks were covered with nylon netting for adequate protection. Clarias gariepinus aged 45 days (length $110 \pm 5 \mathrm{~mm}$ and weight $11.40 \pm 2.46 \mathrm{~g}$ ) were procured from Naihati, Bodtalla fish market, North 24 Parganas district, West Bengal, India. The fish $(n=200)$ were brought to the laboratory, disinfected with 5 ppm potassium permanganate for $10 \mathrm{~min}$ and stocked in the $500 \mathrm{l}$ capacity FRP tanks at a density of $50 \operatorname{tank}^{-1}$ containing 3001 clean bore-well water. The fish were acclimatized for about two weeks, and during this period they were fed with Tubifex sp. and cooked chicken offal at a rate of $2 \%$ body weight. Accumulated wastes and feces were removed once every three days and $50 \%$ of the water was exchanged. Nine each of the healthy fish were selected, released into the experimental tanks, and acclimatized for three days. Two E. tarda strains ( $\mathrm{PB}_{\mathrm{P}}$ and $\left.\mathrm{PB}_{\mathrm{B}}\right)$ isolated from the 
diseased C. gariepinus were used in the bacterial challenge test.

The bacterial strains E. tarda $\left(\mathrm{PB}_{\mathrm{P}}\right.$ and $\left.\mathrm{PB}_{\mathrm{B}}\right)$ maintained on BHIA slants were streaked onto BHIA plates separately and incubated at $30 \pm 2^{\circ} \mathrm{C}$ for $24 \mathrm{~h}$ to obtain a young culture. One colony each of the strains were aseptically picked, transferred to $10 \mathrm{ml}$ BHI broth (BHIB) separately, and incubated at $30 \pm$ $2^{\circ} \mathrm{C}$ for $24 \mathrm{~h}$. Mass culture was done in $500 \mathrm{ml} \mathrm{BHIB}$ at $30 \pm 2^{\circ} \mathrm{C}$ for $24 \mathrm{~h}$ for both the strains separately and centrifuged at $7500 \mathrm{rpm}$ at $20^{\circ} \mathrm{C}$ for $10 \mathrm{~min}$ to collect the cells. The pellets thus obtained were washed three times with sterile physiological saline and suspended in $5 \mathrm{ml}$ saline. The numbers of bacterial cells in the saline suspensions were determined by spread plating on BHIA.

All the experimental tanks (T1 - T8) and control tanks $\left(\mathrm{C}^{+}\right.$and $\left.\mathrm{C}^{-}\right)$contained nine fish each in duplicate and 1001 of clean bore-well water. The cells of $E$. tarda strains from $10^{-1}$ to $10^{-4}$ dilutions were injected intramuscularly at $0.1 \mathrm{ml} \mathrm{fish}^{-1}$ at the dorsal fin base in such a way so as to get $10^{8}-10^{5}$ cells fish $^{-1}$. Positive control fish received sterile saline and negative control received no injection. The challenged fish were maintained in their respective tanks for 22 days and fed daily with Tubifex sp. and cooked chicken offal on demand. Observations of mortality, external signs of infections, cannibalism, and behavioral changes were recorded daily, and based on the mortality data $\mathrm{LD}_{50}$ was determined (Reed and Muench 1938).

\section{Histopathology}

The gills, muscle, liver, and kidney tissues of naturally-infected catfish were fixed in Bouin's solution for $48 \mathrm{~h}$. The fixed samples were prepared histologically using standard techniques, embedded in paraffin wax, and $5 \mu \mathrm{m}$ sections were prepared and stained with hematoxylin and eosin (Roberts 2001).

\section{Results}

The diseased $C$. gariepinus fingerlings showed loss of pigmentation, swelling of the abdominal surface, and petechial hemorrhages in the fins. Internally, mild bloody ascites and inflamed liver, spleen, and kidney were found. The bacterial isolates from the kidney and ascites of diseased catfish were presumptively identified as E. tarda. No E. tarda and/or other bacteria could be isolated from the kidney of healthy catfish. The phenotypic characteristics of two bacterial strains $\left(\mathrm{PB}_{\mathrm{B}}\right.$ and $\left.\mathrm{PB}\right)$ isolated from the kidney of catfish fingerlings with dropsy as assessed with conventional tests and Vitek 2 - Compact (BioMerieux, France) are presented in Tables 1 and 2, respectively. The bacterial strains were confirmed as E. tarda, though they exhibited minor variations in the biochemical characteristics such as L-lactate alkalinization and succinate alkalinization (Table 2).

Table 1

Biochemical characterization of Edwardsiella tarda strains from Clarias gariepinus with dropsy. sR - short rod; w - weak

\begin{tabular}{|c|c|c|}
\hline \multirow[b]{2}{*}{ Biochemical reaction } & \multicolumn{2}{|c|}{ Bacterial strains } \\
\hline & $\begin{array}{l}\text { E. tarda } \\
\mathrm{PB}_{\mathrm{B}}\end{array}$ & $\begin{array}{l}\text { E. tarda } \\
\mathrm{PB}_{\mathrm{P}}\end{array}$ \\
\hline Gram reaction & - & - \\
\hline Morphology & sR & sR \\
\hline Oxidase & - & - \\
\hline O/F reaction (glucose) & $+/+$ & $+/+$ \\
\hline Acid from glucose & + & + \\
\hline Gas from glucose & + & + \\
\hline Acid from mannitol & - & - \\
\hline Motility & + & + \\
\hline Catalase & + & + \\
\hline Arginine dihydrolase & - & - \\
\hline Lysine decarboxylase & + & + \\
\hline Ornithine decarboxylase & + & + \\
\hline Indole production & + & + \\
\hline Methyl red reaction & + & + \\
\hline Voges Proskauer reaction & - & - \\
\hline Protease & - & - \\
\hline Lipase & - & - \\
\hline Amylase & - & - \\
\hline Aesculin hydrolysis & - & - \\
\hline Growth on MacConkey agar & + & + \\
\hline Growth at $4^{\circ} \mathrm{C}$ & - & $+\mathrm{W}$ \\
\hline Growth at $30^{\circ} \mathrm{C}$ & + & + \\
\hline Growth at $37^{\circ} \mathrm{C}$ & + & + \\
\hline Growth in $0 \%$ sodium chloride (w/v) & + & + \\
\hline Pigmentation & - & - \\
\hline Hydrogen sulphide production & + & + \\
\hline Nitrate reduction & + & + \\
\hline Sodium citrate utilization & - & - \\
\hline
\end{tabular}


Table 2

Biochemical characteristics of Edwardsiella tarda strains from diseased Clarias gariepinus as assessed with the Vitek 2 Compact system (Biomerieux, France)

\begin{tabular}{|c|c|c|c|c|c|}
\hline \multirow[b]{2}{*}{ Biochemical characteristics } & \multicolumn{2}{|c|}{$\begin{array}{l}\text { Bacterial strains } \\
\text { and reactions }\end{array}$} & \multirow[b]{2}{*}{ Biochemical characteristics } & \multicolumn{2}{|c|}{$\begin{array}{l}\text { Bacterial strains } \\
\text { and reactions }\end{array}$} \\
\hline & $\mathrm{PB}_{\mathrm{B}}$ & $\mathrm{PB}_{\mathrm{P}}$ & & $\mathrm{PB}_{\mathrm{B}}$ & $\mathrm{PB}_{\mathrm{P}}$ \\
\hline Adonitol (ADO) & - & - & Ala-Phe-Pro-arylamidase (APPA) & - & - \\
\hline Alpha-glucosidase (AGLU) & - & - & Alpha-galactosidase (AGAL) & - & - \\
\hline Beta-glucoronidase (BGUR) & - & - & Beta-alanine arylamidase pNA (BAlap) & - & - \\
\hline Beta-xylosidase (BXYL) & - & - & Beta-galactosidase (BGAL) & - & - \\
\hline Citrate (sodium) (CIT) & - & - & Beta-glucosidase (BGLU) & - & - \\
\hline D-Cellobiose (dCEL) & - & - & $\beta$-N-Acetyl-glucosaminidase (BNAG) & + & - \\
\hline D-Glucose (dGLU) & + & + & Coumarate (CMT) & + & - \\
\hline D-Maltose (dMAL) & + & + & Ellman (ELLM) & + & - \\
\hline D-Mannitol (dMAN) & - & - & Gamma-glutamyl transferase (GGT) & - & - \\
\hline D-Mannose (dMNE) & + & + & Glu-Gly-Arg-arylamidase (GGAA) & - & - \\
\hline D-Sorbitol (dSOR) & - & - & Glutamyl arylamidase pNA (AGLTp) & - & - \\
\hline D-Tagatose (dTAG) & - & - & Glycine arylamidase (GlyA) & - & - \\
\hline D-Trehalose (dTRE) & - & - & L-Pyrrolydonyl-arylamidase (PyrA) & - & - \\
\hline Fermentation/ glucose (OFF) & + & + & L-Histidine assimilation (IHISa) & - & - \\
\hline H2S production (H2S) & + & + & L-Lactate alkalinisation (ILATk) & - & + \\
\hline L-Arabitol (IARL) & - & - & L-Lactate assimilation (ILATa) & - & - \\
\hline Lipase (LIP) & - & - & L-Proline arylamidase (ProA) & - & - \\
\hline L-Malate assimilation (IMLTa) & - & - & Malonate (MNT) & - & - \\
\hline Lysine decarboxylase (LDC) & + & + & O/129 Resistance (0129R) & + & + \\
\hline Orinithine decarboxylase (ODC) & + & + & Palatinose (PLE) & - & - \\
\hline Phosphatase (PHOS) & + & + & Succinate alkalinization (SUCT) & - & + \\
\hline Saccharose/Sucrose (SAC) & - & - & Tyrosine arylamidase (TyrA) & - & - \\
\hline Urease (URE) & - & - & $\beta$-N-acetyl-galactosaminidase (NAGA) & - & - \\
\hline 5-Keto D-gluconate $(5 \mathrm{KG})$ & - & - & & & \\
\hline
\end{tabular}

The time of first mortality among the catfish fingerlings injected with bacterial suspension of $1 \times$ $10^{8}$ cells fish ${ }^{-1}$ was 8 h 49 min for $E$. tarda $\mathrm{PB}_{\mathrm{B}}$ and $11 \mathrm{~h} 30 \mathrm{~min}$ for $E$. tarda $\mathrm{PB}$. All the catfish which received $1 \times 10^{8}$ cells fish $^{-1}$ died within seven days. The challenged catfish fingerlings were observed to be under stress showing symptoms like petechial hemorrhages, inflammation or ulceration at the site of injection, vertical hanging from the water surface, frothing on the water surface due to excess mucus production, listing, swollen abdomen, anorexia, fin and tail rot, and reddish operculum. The $\mathrm{LD}_{50}$ of $E$. tarda $\mathrm{PB}_{\mathrm{B}}$ and $\mathrm{PB}_{\mathrm{P}}$ strains were found to be $8.52 \times$ $10^{6}$ cells fish $^{-1}$ and $1.68 \times 10^{7}$ cells fish $^{-1}$, respectively. The severity of fin and tail rot on catfish when challenged with E. tarda increased with each passing day post-challenge.

The histopathological alterations of ulcerated muscle area, gills with reddish operculum, liver and kidney of $C$. gariepinus with dropsy are documented in Figs. 1-6. Infiltration of lymphocytes was seen in the muscle of ulcerated $C$. gariepinus (Fig. 1). The gills had focal necrosis in the filament, hyperplasia, edema, and swelling of the lamellar epithelium (Fig. 2). The kidney of diseased $C$. gariepinus exhibited ischemic type tubulopathy, necrosis of nephritic tubules, hyperplastic hematopoietic tissue, partial rupture of tubular basement membrane, hydropic dystrophy of individual nephritic cells (Fig. 3), neutrophil infiltration, fibrinoid necrosis of nephretic 


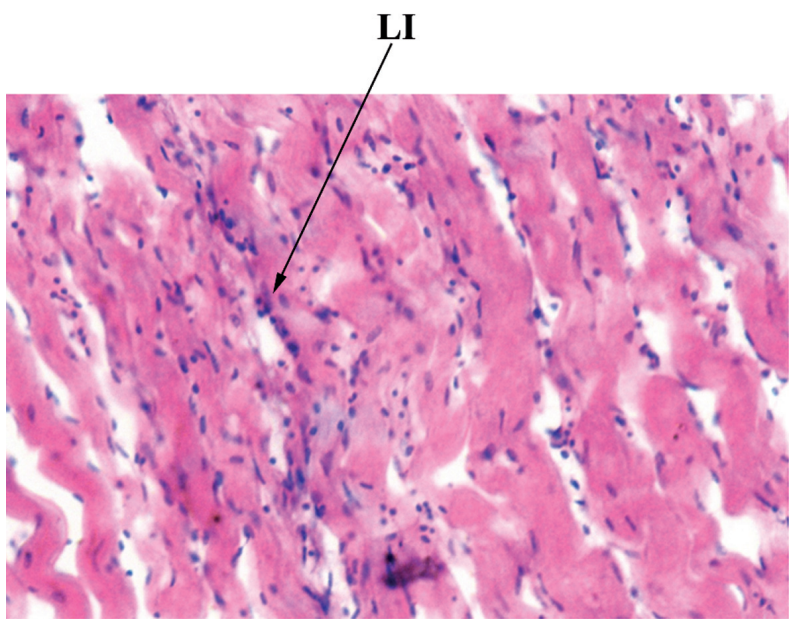

Figure 1. Photomicrograph of muscle showing lymphocytic infiltration (LI) (hematoxylin and eosin stain; x200).

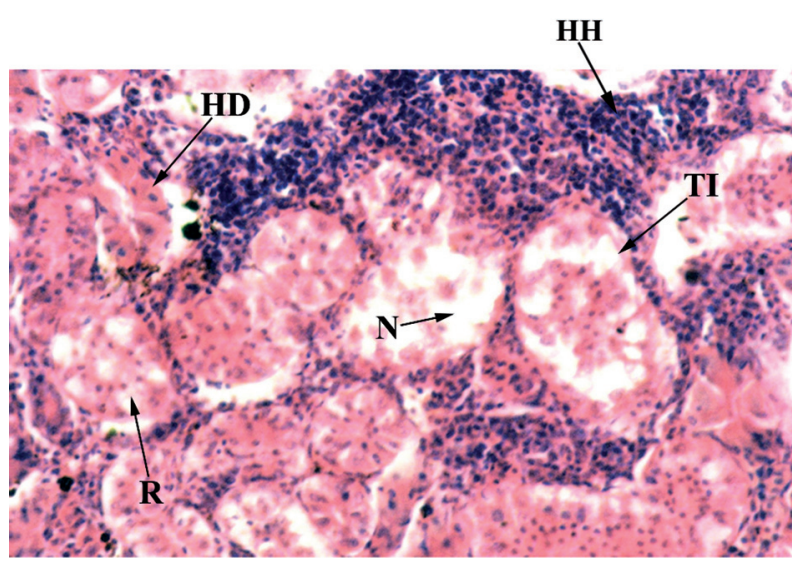

Figure 3. Photomicrograph of kidney showing ischemic type tubulopathy (TI), necrosis of nephritic tubules (N), rupture of tubular basement membrane (R) and hydropic dystrophy of nephretic cells (HD) (hematoxylin and eosin stain; x200).

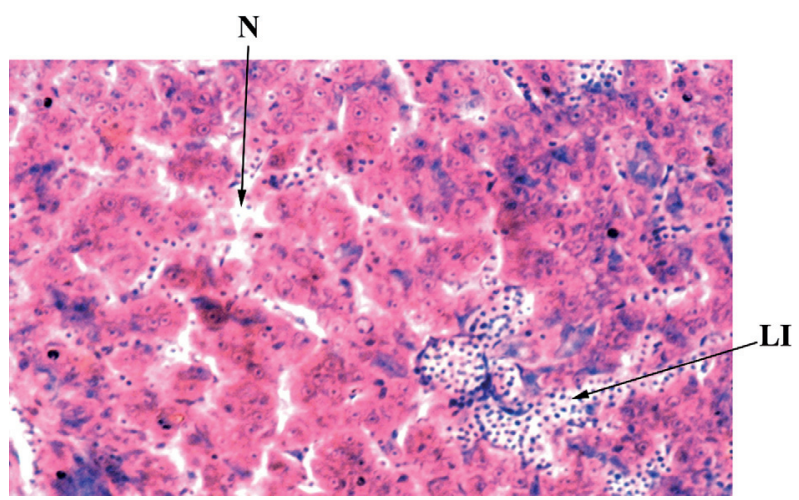

Figure 5. Photomicrograph of liver showing necrosis $(\mathrm{N})$ and lymphocytic infiltration (LI) (hematoxylin and eosin stain; x200).

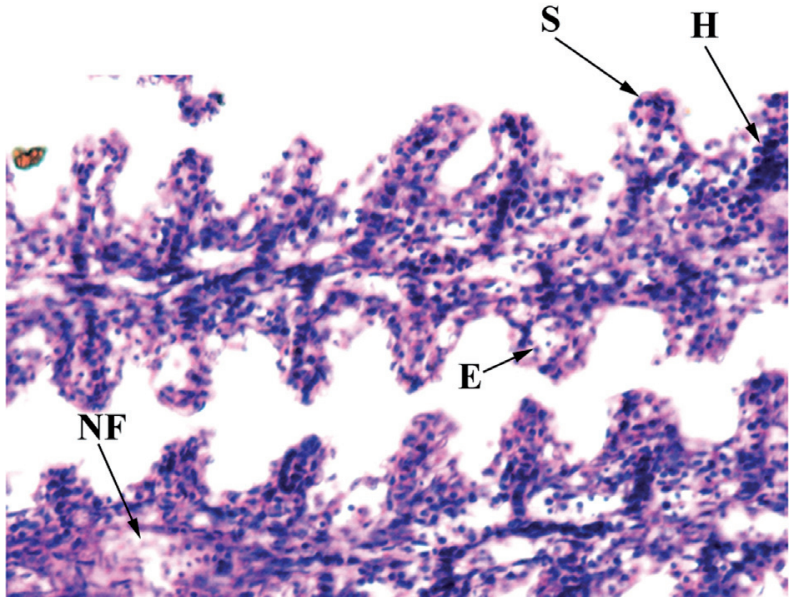

Figure 2. Photomicrograph of gill showing focal necrosis in the gill filament (NF), hyperplasia (H), edema (E) and swelling (S) of lamellar epithelium (hematoxylin and eosin stain; x200).

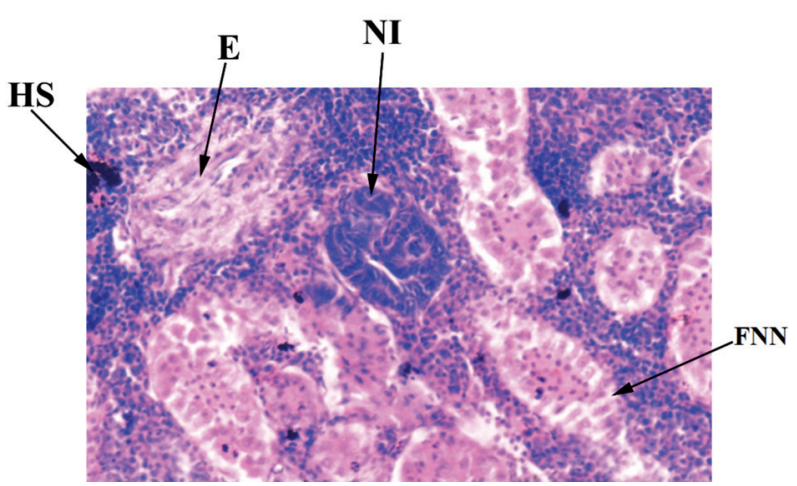

Figure 4. Photomicrograph of kidney showing neutrophil infiltration (NI), hemosiderin deposition (HS), fibrinoid necrosis of nephretic tubules (FNN), and edema (E) (hematoxylin and eosin stain; x200).

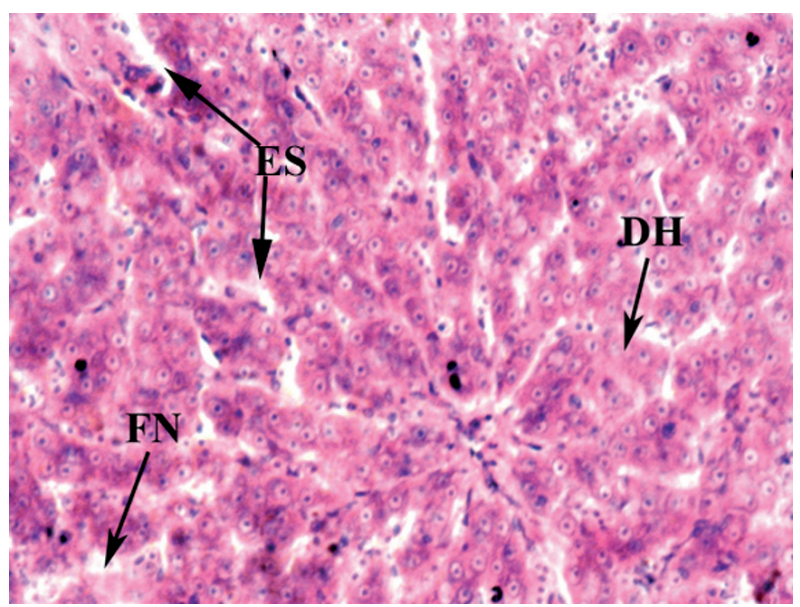

Figure 6. Photomicrograph of liver showing expansion of space between hepatic sinusoids (ES), dilation of hepatic sinusoids (DH), and focal necrosis (FN) (hematoxylin and eosin stain; $\mathrm{x} 200)$. 
tubules, hemosiderin deposition, and edema (Fig. 4). The liver sections showed focal necrosis and lymphocyte infiltration (Fig. 5), dilation of hepatic sinusoids, expansion of space between hepatic sinusoids, and focal necrosis (Fig. 6).

\section{Discussion}

In the present study, the isolation and identification of E. tarda from the kidney of diseased C. gariepinus fingerlings indicated edwardsiellosis. Edwardsiella tarda infection in fish usually occurs under imbalanced environmental conditions such as high water temperature, poor water quality, and high organic content (Park et al. 2012). Both E. tarda $\mathrm{PB}_{\mathrm{B}}$ and $\mathrm{PB}_{\mathrm{P}}$ strains were moderately virulent as per the degree of virulence (Pu et al. 2007) and the observed $\mathrm{LD}_{50}$ values $\left(8.52 \times 10^{6}\right.$ cells fish $^{-1}$ and $1.68 \times 10^{7}$ cells fish ${ }^{-1}$ ) on $C$. gariepinus fingerlings by intramuscular injection. These moderately virulent E. tarda strains caused swollen abdomen when challenged in healthy fish. Besides, the challenged catfish fingerlings exhibited hemorrhage spots, vertical hanging, frothing, excess mucus production, listing, anorexia, fin and tail rot, and reddish operculum. The above results are, more or less, similar to the observation $\left(10^{7.8}\right.$ cells $\left.\mathrm{ml}^{-1}\right)$ reported for intraperitonially injected Anabas testudineus (Sahoo et al. 2000). Contrary to the present study, $\mathrm{LD}_{50}$ values of $4.0 \times 10^{5}$ cells fish ${ }^{-1}$ for intramuscularly injected Ictalurus punctatus (Amandi et al. 1982) and $7.1 \times 10^{1}$ cells fish $^{-1}$ for intramuscularly injected Paralichthys olivaceus (Mekuchi et al. 1995) were reported.

Infiltration of lymphocytes in the muscle fibers of ulcerated $C$. gariepinus indicated the activation of the first line of defense to ward off the invading bacterial pathogen. Likewise, lymphocytic infiltration in the musculature of Oreochromis niloticus with edwardsiellosis was reported (Nagla et al. 2005). Meyer and Bullock (1973) observed the development of abscesses in the muscle of $I$. punctatus; while Mohanty et al. (2007) reported liquefaction and gaseous necrosis in body musculature of Labeo rohita, infected with E. tarda, leading to ulcer formation. The gills of $C$. gariepinus were found to have filament necrosis, hyperplasia, edema, and swelling of lamellar epithelium. Mohanty et al. (2007) also reported hyperplastic changes in the gills of $L$. rohita infected with E. tarda. These changes could reduce the surface area for effective respiration, which severely stresses fish, or can even lead to death from lack of oxygen. Therefore, a negative impact on respiratory and physiological functions can generally be assumed.

The histopathological alterations such as ischemic type tubulopathy, partial rupture of tubular epithelium and hydropic dystrophy of individual nephritic cells on the kidney of $C$. gariepinus fingerlings indicated acute renal failure. This was further proved by the presence of fibrinoid necrosis of nephritic tubules, thereby indicating the severity of disease processes induced by E. tarda infection. Neutrophil infiltration combined with the proliferation of endothelial and intraglomerular mesangial cells were also noted in the glomerular capillaries. Hemosiderin deposition was an indication of defense responses. These irreversible changes in the kidney of diseased fish possibly led to mortalities and a production loss of about $22 \%$ in the affected pond. The expansion of space between hepatic sinusoids, dilation of hepatic sinusoids, focal necrosis, and lymphocyte infiltration in the liver reflected the course of inflammatory processes involving macrophages against the E. tarda invasion. The hepatocytes were either hypertrophoid or necrotic, which is in accordance with Blazer et al. (2007) as noted in the liver of Ameiurus nebulosus. The histopathological alterations of the present study are in agreement with those observed in C. gariepinus (Ibrahem et al. 2010, 2011), P. olivaceus (Miwa and Mano 2000), Scophthalmus maximus (Padros et al. 2006) and I. punctatus (Raidal et al. 2004) infected with $E$. tarda. The inflammatory responses observed in kidney and liver of the present study were presumably suppuration. However, some authors described these responses as granulomatous in Pagrus major (Miyazaki and Kaige 1985) and O. niloticus (Pirarat et al. 2007). 


\section{Conclusion}

The observed necrotic and degenerative changes on C. gariepinus can be attributed to the potential virulence factors of $E$. tarda. Understanding the virulence potentials of E. tarda in catfish can facilitate the development of protective measures against its infection.

Acknowledgements. The research work was financed by the Indian Council of Agricultural Research, Government of India, New Delhi under the Niche Area of Excellence program.

Author contributions. T.J.A. contributed substantially to the concept and design, drafted the article, and revised it critically. P.K.M. collected and maintained the fish, analyzed the samples, and generated laboratory data. H.A. was involved in the maintenance and phenotypic characterization of bacterial isolates. S.B. contributed substantially histologically and on the interpretation of histopathological changes.

\section{References}

Amandi A., Hiu S.F., Rohovec J.S., Fryer J.L. 1982 - Isolation and characterization of Edwardsiella tarda from chinook salmon (Oncorhynchus tshawytscha) - Appl Environ Microbiol. 43: 1380-1384.

Austin B., Austin D.A. 2012 - Bacterial fish pathogens: disease of farmed and wild fish, $5^{\text {th }}$ edition - Springer-Praxis in Aquaculture in Fisheries, Praxis Publication Ltd, Chichester, UK, $457 \mathrm{p}$.

Blazer V.S., Fournie J.W., Wolf J.C., Wolf M.J. 2007 - Manual for the microscopic diagnosis of proliferative liver and skin lesions in the brown bullhead (Ameiurus nebulosus) - Pennsylvania Sea Grant and the National Oceanic and Atmospheric Administration, USA, 34 p.

Collins C.H., Lyne P.M., Grange J.M., Falkinham III J.O. 2004 - Collins and Lyne's Microbiological methods, $8^{\text {th }}$ edition - Arnold, London, UK, 456 p.

DAHDF (Department of Animal Husbandry, Dairying and Fisheries) 2012 - Handbook on fisheries statistics 2011 Ministry of Agriculture, Govt. of India, New Delhi, India, $170 \mathrm{p}$.

Declercq A.M., Haesebrouck F., Van den Broeck W., Bossier P., Decostere A. 2013 - Columnaris disease in fish: a review with emphasis on bacterium-host interactions Vet. Res. 44: 27.

Hidalgo B.R., Figueras M.J. 2012 - Molecular detection and characterization of furunculosis and other Aeromonas fish infections - In: Health and Environment in Aquaculture (Eds) E.D. Carvalho, G.S. David, R.J. Silva, InTech, Rijeka, Croatia, 97-132 pp.

Ibrahem M.D., Atta A.H., Shalaby M.A. 2010 - Bioavailability of orbifloxacin in African sharptooth catfish, Clarias gariepinus, and its efficacy in control of induced Edwardsiellosis - J. Am. Sci. 6: 236-244.

Ibrahem M.D., Shaheed B., Yazeed H.A.E., Korani H. 2011 Assessment of the susceptibility of polyculture reared African catfish and Nile tilapia to Edwardsiella tarda - J. Am. Sci. 7: 779-786.

Mekuchi T., Kiyokawa T., Honda K., Nakai T., Muroga K. 1995 - Infection experiments with Edwardsiella tarda in the Japanese flounder - Fish Pathol. 30: 247-250.

Meyer F.P., Bullock G.L. 1973 - Edwardsiella tarda, a new pathogen of channel catfish (Ictalurus punctatus) - Appl. Microbiol. 25: 155-156.

Miwa S., Mano N. 2000 - Infection with Edwardsiella tarda causes hypertrophy of liver cells in Japanese flounder Paralichthys olivaceus - Dis. Aquat. Org. 42: 227-231.

Miyazaki T., Kaige N. 1985 - Comparative histopathology of edwardsiellosis in fishes - Fish Pathol. 20: 219-227.

Mohanty B.R., Sahoo P.K. 2007 - Edwardsiellosis in fish: a brief review - J. Biosci. 32: 1331-1344.

Mohanty B.R., Sahoo P.K., Mahapatra K.D., Saha J.N. 2007 Innate immune responses in families of Indian major carp, Labeo rohita, differing in their resistance to Edwardsiella tarda infection - Curr. Sci. 92: 1270 -1274.

Nagla F., Galal-Safinaz G.M., Ismail R.H.K., Soliman M.K. 2005 - Studies on Edwardsiella infection in Oreochromis niloticus - Egyptian J. Aquat. Res. 31: 460-471.

Padros F., Zarza C., Dopazo L., Cuadrado M., Crespo S. 2006 - Pathology of Edwardsiella tarda infection in turbot, Scophthalmus maximus (L.) - J. Fish Dis. 29: 87-94.

Park S.B., Aoki T., Jung T.S. 2012 - Pathogenesis of and strategies for preventing Edwardsiella tarda infection in fish Vet Res. 43(1): 67.

Pirarat N., Maita M., Endo M., Katagiri T. 2007 - Lymphoid apoptosis in Edwardsiella tarda septicemia in tilapia, Oreochromis niloticus - Fish Shellfish Immunol. 22: 608-616.

Pu J.Y., Huang X.X., Lu C.P. 2007 - Virulence detection of Streptococcus suis type 2 in zebra fish - Scientia Agri. Sinica 40: 2655-2658.

Raidal S., Cross G., Fenwick S., Nichollas P., Nowak B., Ellard K., Stephen F. 2004 - Aquatic animal health: Exotic disease training manual - Fisheries Research and Development Corporation and Murdoch University, Murdoch, Australia, 164 p. 
Reed L.J., Muench S. 1938 - A simple method of estimating fifty percent end point - Am. J. Epidemiol. 27: 493-497.

Roberts R.J. 2001 - Fish Pathology, 3rd edition - WB Saunders, London, 472 p.

Sahoo P.K., Swain P., Sahoo S.K., Mukherjee S.C., Sahu A.K. 2000 - Pathology caused by the bacterium Edwardsiella tarda in Anabas testudineus (Bloch) - Asian Fish Sci. 13: 357-362.
Singh A.K., Lakra W.S. 2011 - Risk and benefit assessment of alien fish species of the aquaculture and aquarium trade into India - Rev. Aquacult. 3: 3-18.

Thakur N.K. 1998 - A biological profile of the African catfish Clarias gariepinus and impacts of its introduction in Asia - In: Fish genetics and biodiversity conservation (Eds) A.G. Ponniah, P. Das, S.R. Verma, Natcon Publications, Muzzafarnagar (UP), India, 275-292. 